\title{
pemujaAn leluhur di Kepulauan maluKu TENGGARA: \\ JEJAK BUDAYA MATERI DAN PERANNYA BAGI STUDI ARKEOLOGI KAWASAN
}

\author{
Ancestor Worship in Southeast Maluku Islands: \\ Traces of material culture and its role in the study of regional archaeology
}

Oleh Marlon NR Ririmasse

Balai Arkeologi Ambon

Jl. Namalatu-Latuhalat Ambon 97118

Email: ririmasse@yahoo.com

\begin{abstract}
Abstrak
Pemujaan leluhur adalah salah satu aspek penting dalam konstruksi sosial masyarakat masa lalu di Kepulauan Maluku Tenggara. Model kepercayaan tradisional ini berlangsung setidaknya hingga pergantian abad ke-20 menyusul introduksi agama modern di wilayah ini. Praktek pemujaan leluhur juga dimanifestasi secara materi dalam ragam produk budaya masa lalu di Kepulauan Maluku Tenggara. Tulisan ini mencoba untuk meninjau kembali aktivitas pemujaan leluhur masa lalu dalam kawasan dan secara khusus berusaha mengamati bentuk-bentuk representasi material atas aktivitas khas ini. Diskusi atas peran tema spesifik ini dalam studi arkeologi akan dihadirkan untuk melengkapi opsi tema penelitian yang sejalan dengan karakter Kepulauan Maluku Tenggara. Observasi lapangan dan studi pustaka dipilih sebagai pendekatan dalam kajian ini. Hasil penelitian menemukan bahwa pemujaan leluhur dipraktekkan secara luas pada masa lalu di Kepulauan Maluku Tenggara. Wahana pemujaan umumnya ditampilkan dalam bentuk patung dengan ciri beragam antarsatu komunitas dengan komunitas lainnya serta berasosiasi dengan rencana ruang tradisional. Akhirnya, pengetahuan spesifik terkait religi masa lalu ini dapat menjadi wahana untuk memperkaya kedalaman kajian arkeologi dan sejarah budaya dalam kawasan.
\end{abstract}

Kata kunci: pemujaan leluhur, budaya materi, Kepulauan Maluku Tenggara.

\section{Abstract}

Ancestor worship is one of the important aspects in social construction of past society in Southeast Maluku Islands. This traditional model of beliefs lasted, at least, up to the change of $20^{\text {th }}$ century following the introduction of modern religions in the region. It is manifested materially in various products of past culture. The purpose of this research is to review past ancestor-worship activities in the region and, specifically, try to observe forms of material representations of this unique activity. The author presents discussion 
on the role of this specific theme in archaeological study in line with characteristics of the Southeast Maluku Islands. Field observation and bibliographical study are chosen for this study. The author finds that ancestor worship was practiced vastly in Southeast Maluku Islands in the form of statues that had various characteristics from one community to another, and it was associated with the traditional space design. It is hoped that this research would become a way to enrich the depth of archaeological study and culture history in a region.

Keywords: ancestor worship, material culture, Southeast Maluku Islands.

\section{A. PENDAHULUAN}

Mereka yang pernah menetap atau berkunjung ke Kepulauan Maluku Tenggara setidaknya sempat mengamati keberadaan aneka ukiran patung yang sering ditawarkan sebagai sovenir. Karakter khas patung-patung ini biasanya terbuat dari kayu hitam yang direka dalam aneka ukuran. Seni kriya patung memang merupakan salah satu penanda utama dalam profil tradisi budaya bendawi di Maluku Tenggara. Motif yang ditampilkan bervariasi. Namun bentuk antromorfik (manusia) dalam berbagai laku adalah salah satu katagori representasi yang paling dominan. Dalam konsep budaya masyarakat Kepulauan Maluku Tenggara, tema manusia yang divisualisasikan biasanya mewakili dua unsur utama: representasi Illahi (dewa) dan manifestasi leluhur.

Tema leluhur memang merupakan salah satu elemen kunci dalam profil budaya masa lalu di Kepulauan Maluku Tenggara. Keberadaan figur para pendahulu ini adalah esensial dalam kaitan dengan pengetahuan religi masa lalu di wilayah ini. Sebelum masuknya agama Islam dan introduksi agama Kristen, ragam patung leluhur menjadi bagian dari religi masyarakat di kawasan ini. Mereka ditempatkan di altar khusus dalam rumah tinggal dan di mezbah batu yang biasanya dikonstruksi di tengah pemukiman. Saat ini bentuk-bentuk keyakinan tradisional seperti ini memang sudah hampir menghilang dari Kepulauan Maluku Tenggara. Namun jejak religi khas ini masih dapat diamati dari keberadaan beragam wahana materi masa lalu terkait pemujaan leluhur.
Sejauh ini perhatian spesifik yang mencoba mengamati bentuk-bentuk wahana pemujaan leluhur di Kepulauan Maluku Tenggara dapat dikatakan masih sangat minimal. Demikian halnya dengan kajian yang mencoba mengamati latar sejarah dan aspek gagasan yang melandasi praktik religi khas ini. Padahal, menimbang karakternya yang unik, pengetahuan spesifik terkait religi masa lalu ini dapat menjadi salah satu sumber utama untuk menjelaskan dinamika sosial masa lalu di Kepulauan Maluku Tenggara. Tulisan ini mencoba menjadi wahana untuk menciptakan ruang diskusi pada tahap mula tentang tema spesifik ini dalam kaitan dengan pengembangan studi arkeologi di Kepulauan Maluku Tenggara.

Pemujaan leluhur adalah bagian dari profil budaya masa lalu di Kepulauan Maluku Tenggara. Tradisi mengenang para pendahulu ini dipraktikkan secara kolosal pada masa lalu dalam wilayah ini. Meski demikian, perhatian secara akademis atas isu spesifik dimaksud masih sangat minimal. Situasi ini dapat dilihat dari minimnya referensi terkait tema pemujaan leluhur dalam berbagai kajian sejarah budaya Maluku. Berpijak pada kondisi tersebut tulisan ini mencoba menjawab tiga masalah dalam isu spesifik ini:

1. Bagaimanakah latar historis praktek pemujaan leluhur di Kepulauan Maluku Tenggara pada masa lalu?

2. Bukti-bukti materi apa yang dapat menjadi acuan praktik religi khas ini?

3. Bagaimanakah peran pengetahuan spesifik ini bagi pengembangan 
studi arkeologi dan sejarah budaya dalam kawasan?

Mengacu pada permasalahan yang diajukan di atas, maka tujuan penelitian ini adalah: Pertama, mengetahui latar historis pemujaan leluhur masa lalu di Kepulauan Maluku Tenggara; Kedua, menemukan bukti-bukti materi terkait praktik khas ini; Ketiga, mengidentifikasi peran khas pengetahuan spesifik ini bagi pengembangan studi arkeologi dan sejarah budaya dalam kawasan.

Proses pengumpulan data dalam kajian ini dilakukan dengan dua pendekatan yaitu survei dan studi pustaka. Data yang dikumpulkan melalui survei merupakan kompilasi data yang dihimpun melalui beberapa kegiatan pengamatan di lapangan. Dalam kegiatan survei ini yang menjadi perhatian adalah objek-objek yang memiliki keterkaitan dengan praktik pemujaan leluhur masa lalu. Studi pustaka dilakukan untuk meninjau segenap data sejarah dan budaya terkait praktik spesifik ini di masa lalu. Tinjauan pustaka juga dilakukan untuk menemukan gagasan konseptual dan teoritis terkait tradisi pemujaan leluhur sebagai bagian dari upaya empiris menjawab pertanyaan penelitian.

\section{Pemujaan Leluhur dalam Teori: Antara Religi dan Identitas}

Wajah sejarah budaya umat manusia senantiasa melekat dengan kebutuhan akan pengenalan jati diri serta asal usul individu dan kelompok. Hakikat sebagai pribadi dan ikatan sebagai bagian dari suatu kelompok ditandai dengan keberadaan elemenelemen khas yang mencerminkan kondisi spesifik dimaksud. Genealogi merupakan salah satu aspek yang digunakan sebagai penanda untuk mengikat individu dan kelompok secara sosial. Dalam konteks ini, hubungan darah dan kekerabatan menjadi acuan utama untuk meninjau asal usul individu dan kelompok. Kebersamaan secara sosial di sisi lain juga dapat diikat secara konvensional. Melalui sudut pandang ini, keterkaitan antarindividu dan kelompok menjadi lebih kompleks karena direkat dengan pertimbangan aspek sosial, ekonomi, politis hingga historis. Persamaan kebutuhan dan kepentingan menjadi faktor utama bagi individu pun kelompok di masa lalu untuk membentuk suatu komunitas pertama.

Peran individu dan kelompok pertama ini dapat dianalogikan sebagai founding fathers atau para pendahulu yang menjadi penggagas dibentuknya suatu komunitas. Seiring waktu ketika jumlah anggota bertumbuh dan berganti dalam lintas generasi, para pionir ini seringkali tetap memiliki peran sentral dalam komunitas dan menjadi acuan utama dalam meninjau asal-usul suatu kelompok. Leluhur (ancestor), sejatinya memang telah menjadi bagian penting dalam konstruksi sejarah budaya manusia. Hal ini dapat diamati lewat ragam bentuk penghormatan kepada leluhur dan aneka ritual kompleks yang melingkupinya, sebagai fenomena yang ditemukan di berbagai pelosok dunia. Bukan hal baru kiranya jika disebutkan bahwa pada derajat tertentu, leluhur bahkan diberi peran yang berkelanjutan dalam konstruksi sosial komunitas yang masih hidup. Leluhur ditempatkan sebagai entitas yang menjadi bagian integral dalam keseharian komunitas. Kehadiran mereka dipandang memiliki daya yang memengaruhi dinamika sosial masyarakat. Karena itu leluhur kemudian dikeramatkan, diberi peran sakral, dilekatkan menjadi bagian yang menyatu dengan religi tradisional dan dipuja sebagai salah satu kekuatan yang menentukan stabilitas alam dan sosial.

Bentuk-bentuk penghormatan dan pemujaan leluhur dapat dipahami sebagai praktek religi yang memberi ruang bagi peran individu-individu yang telah mati dalam keseharian mereka yang masih hidup. Kamus bahasa Inggris Webster menjelaskan pemujaan leluhur (ancestor worship) sebagai "the custom of venerating deceased ancestors who are considered still a part of the family and whose spirits 
are believed to have the power to intervene in the affairs of the living". Definisi di atas agaknya serupa dengan pandangan Dhavamony (1995) yang mencoba menjelaskan dengan lebih spesifik bahwa pemujaan leluhur merupakan suatu kumpulan sikap, kepercayaan dan praktik yang berhubungan dengan pendewaan orang-orang yang sudah meninggal dalam satu komunitas, khususnya dalam kaitan dengan hubungan kekeluargaan. Paul Radin (1991) mengemukakan bahwa pemujaan leluhur adalah bentuk-bentuk ritual yang menyamakan leluhur, dari garis keluarga atau komunitas, dengan roh atau dewa. Pijakan utama konsep pemujaan leluhur memang diletakkan pada rangkaian tindakan yang bertujuan melestarikan kehadiran leluhur dalam kehidupan keseharian individu dan kelompok yang masih hidup.

Tradisi dan ritual pemujaan leluhur memang telah menjadi bagian penting dalam mekanisme sosial masyarakat secara universal. Di mana pemujaan leluhur tidak semata dipandang sebagai praktik religi dengan nuansa abstrak namun meluas menjadi bagian dari mekanisme kontrol sosial untuk mengikat kebersamaan sebagai kelompok dan komunitas. Kehadiran leluhur dipandang sebagai elemen yang menghadirkan memori kolektif tentang asal-usul sebagai satu kelompok. Leluhur dan kompleksitas tradisi dan ritual yang melingkupinya dikonstruksi secara sosial sebagai wahana yang melegitimasi masa lalu dalam konteks kekinian (Connerton, 1989). Melalui kehadiran leluhur dalam struktur sosial, garis keturunan mendapatkan legitimasinya atas berbagai aspek kehidupan mencakup politik hingga ekonomi. Dengan demikian, tradisi dan ritual mewujud sebagai bentuk representasi simbolis yang dikonstruksi untuk menghadirkan konsep dimaksud dalam ruang dan waktu yang berbeda (Leach, 1968). Ragam praktek khas ini menjadi mata rantai yang menghubungkan satu generasi ke generasi lainnya dalam satu ikatan identitas (Bell, 1992). Melalui ritual, relasi dan ikatan sosial dipelihara; ikatan melalui garis keturunan dieratkan; dan kesadaran akan akar jati diri bersama sebagai kelompok dijaga. Dalam konteks yang lebih spesifik, ritual kemudian menjadi wahana untuk mempertegas eksistensi otoritas dan struktur sosial dalam masyarakat (Dillehay, 1990).

Hastorf (2003: 306) menyatakan bahwa identitas individu dan kelompok saling kait mengkait dan bahwa karakter khusus tersebut dibentuk oleh relasi-relasi antara manusia dan budaya bendawi dalam lingkungannya. Melalui kaitan antara identitas individu dan kelompok inilah memori kolektif memainkan peran sosialnya sebagai elemen yang menyatukan aspek ideologis dalam ruang komunitas dengan ragam budaya bendawi terkait. Keberadaan benda-benda spesifik yang menjadi penanda karakteristik kelompok dapat dipandang sebagai materialisasi identitas yang menjadi wahana untuk mengikat kebersamaan komunal (De Marrais, 1996). Pemujaan leluhur beserta segenap ritual dan budaya bendawi terkait, dapat dipahami sebagai salah satu manifestasi atas konsep kompleks dimaksud.

\section{B. HASIL DAN BAHASAN}

\section{Pemujaan Leluhur: Tinjauan Lintas Budaya}

Pemujaan leluhur sebagai fenomena budaya memang merupakan praktik yang universal sifatnya. Bentuk-bentuk tindakan khas ini dikenal sejak masa lalu pada beragam komunitas di berbagai belahan dunia. Kebudayaan Cina misalnya yang dikenal sebagai salah satu acuan sejarah budaya dunia, menempatkan pemujaan leluhur sebagai salah satu elemen sentral yang tertua. Leluhur menjadi tempat untuk meminta nasihat dan petunjuk yang hadir dalam bentuk ramalan-ramalan tradisional. Menimbang penghormatan kepada orang tua adalah salah satu inti dari ajaran-ajaran klasik di Cina seperti Konfusianisme, maka ritual dalam bentuk pemujaan leluhur tampil dengan cukup dominan (Carpenter, 1996: 503-517). 
Pemujaan leluhur juga dipraktikkan di Jepang untuk mengembangkan perasaan kekeluargaan yang kuat. Pemujaan terhadap leluhur kerajaan dan keluarga merupakan unsur yang penting dalam agama Shinto. Dalam pemahaman khas dimaksud, kematian dipandang sebagai jalan bagi manusia untuk menjadi kami, unsur yang transenden, namun diyakini tetap aktif di antara mereka yang hidup. Upacara kerajaan dan keluarga biasanya ditujukan kepada para leluhur selain kepada para dewa (kami-dana) (Dhavamony, 1995).

Orang-orang Maya di Semenanjung Yucatan dan Dataran Tinggi Guetemala, Amerika, memiliki tradisi yang melekat dengan kehadiran leluhur dalam kehidupan sehari-hari. Jasad leluhur biasanya disimpan di bawah lantai rumah, di dalam struktur tembok-tembok pemukiman, hingga pada piramida dengan aneka ukuran di tengah pemukiman. Sebuah fenomena yang kiranya serupa dengan profil raya budaya Mesir yang juga membangun piramida sebagai bentuk ingatan bersama terhadap firaun (Dhavamony, Ibid).

Suku-suku tradisional di Afrika juga menempatkan roh-roh leluhur sebagai elemen utama yang mengatur kehidupan sosial masyarakat. Mizimu (roh-roh leluhur) menjadi kepercayaan yang menyatukan kelompok-kelompok suku yang hidup menyebar di Tonga. Karenanya hubungan keluarga dan kekerabatan menjadi faktor penentu dalam penentuan leluhur. Dengan otoritas ini penghormatan dengan sendirinya datang dari garis keturunan. Karenanya pemujaan leluhur menjadi salah satu praktik sosial yang membangun solidaritas kelompok dalam masyarakat Afrika (Dhavamony, Ibid.).

Masyarakat Walbiri di Australia bahkan memiliki keyakinan yang terbilang unik. Dalam kosmologi komunitas ini leluhur dipercaya hidup dalam alam mimpi atau siklus waktu nenek moyang yang dikenal sebagai djugurba. Figur-figur leluhur kemudian divisualisasikan melalui bentuk-bentuk pola hias berkarakter totemik. Karya seni dalam sudut pandang suku Yolngu adalah perlambang kehadiran leluhur dari masa lalu pada masa kini. Ragam representasi visual tentang leluhur juga dipandang sebagai wahana utama dimana gagasan dan pengetahuan tentang leluhur di masa lalu diteruskan dari satu generasi ke generasi yang lain (Morphy, 1993).

Pemujaan leluhur juga dipraktikkan secara luas di wilayah Kepulauan Asia Tenggara. Berbagai komunitas tradisional yang mendiami wilayah ini memiliki tradisi yang lekat dengan komemorasi leluhur dalam kehidupan sehari-hari. Bentuk-bentuk praktik pemujaan yang ditampilkan juga sangat beragam. Baik dalam aspek profil ritual maupun representasi material atas praktik khas ini. Masyarakat Boronadu di Nias, Pantai Barat Sumatera misalnya, di masa lalu selalu menyimpan patung perwujudan nenek moyang yang dikenal sebagai $A d u N u w u$ (Sonjaya, 2008). Orang Pakpak di Sumatera Utara juga mengenal komemorasi leluhur melalui pengarcaaan si mati yang dikenal sebagai Mejan. Objek ini merupakan arca batu dengan bentuk manusia yang menunggang kuda atau gajah. Terkait dengan kematian dan penguburan kedua, Mejan seringkali juga menjadi media untuk berhubungan dengan roh leluhur (Wiradnyana, 2011: 178).

Demikian halnya dengan masyarakat tradisional Kodi dan Anakalang di Pulau Sumba yang mengenal konsep rumah leluhur atau uma. Keberadaan uma dipandang sebagai locus keluarga pertama yang menjadi cikal bakal dari seluruh keluarga yang ada dalam komunitas. Karena itu benda-benda berharga dan keramat yang menjadi wahana ritual desa biasanya disimpan di rumah ini. Praktik pemujaan leluhur pada masyarakat tradisional di Sulawesi bisa diamati pada masyarakat Toraja. Selain memuja Penguasa Langit (Puang Matua) dan Penguasa Bumi (Puang Titanan Tallu), komunitas tradisional Toraja juga memuja 
leluhur yang biasanya disebut sebagai Tomebali Puang. Praktik komemorasi leluhur ini jelas ditunjukkan lewat praktik upacara adat yang dikenal sebagai rambu solok (Mahmud, 2008: 161). Manifestasi material atas penghargaan kepada leluhur ini dapat diamati lewat keberadaan Tau-tau yang terkenal dan Simbuang: objek dengan bentuk serupa menhir yang didirikan pada lokasi ritual. Masyarakat tradisional Toraja memang meyakini bahwa leluhur mereka datang dari utara dan membawa serta kebudayaan dengan karakter megalitik (Mahmud, 2008: 166-167).

Pengaruh praktik pemujaan leluhur ini juga meluas hingga ke pulau-pulau di Timur Nusantara dan menjangkau Kepulauan Maluku Tenggara. Sampai dengan menjelang paruh pertama abad ke20, pemujaan leluhur masih menjadi rujukan utama dalam praktik religi tradisional di kawasan ini. Jejak objek yang kolosal dari praktik khas ini menjadi penanda materi fenomena dimaksud. Bukan semata besar dari segi jumlah namun juga meliputi sebarannya yang menjangkau seluruh kawasan Kepulauan Maluku Tenggara.

\section{Tinjauan Historis Pemujaan Leluhur}

\section{di Kepulauan Maluku Tenggara}

Maluku Tenggara sejatinya memang merupakan kawasan kepulauan yang luas dan kompleks. Membentang antara Timor dan Papua, wilayah ini dibentuk oleh beberapa kepulauan utama seperti Kepulauan Tanimbar, Kei dan Aru di ujung paling timur. Selain ketiga gugus pulau tersebut, terdapat juga kelompokkelompok kepulauan yang lebih kecil di sebelah barat yang antara lain mencakup: Kepulauan Babar, Kepulauan Leti Moa Lakor, serta Wetar dan pulau-pulau satelitnya.

Sebelum abad ke-15, religi tradisional yang meliputi praktik pemujaan leluhur merupakan rujukan utama kepercayaan masyarakat di Kepulauan Maluku Tenggara. Kondisi ini berangsur berubah dalam empat abad ke depan menyusul masuknya pengaruh Islam dan diluaskannya ajaran Nasrani oleh Pemerintah Hindia Belanda. Masuk dan berkembangnya pengaruh Islam ini tidak lepas dari keberadaan Kepulauan Maluku Tenggara sebagai salah satu kawasan sumber komoditi eksotik di Kepulauan Maluku. Jika Banda menjadi kawasan sumber untuk pala dan Maluku Utara menjadi produsen utama cengkeh, maka Kepulauan Maluku Tenggara menjadi wilayah penghasil untuk komoditi spesifik seperti bulu burung cendrawasih dan mutiara di Aru serta budak belian dan aneka hasil laut di pulau-pulau lain. Pengaruh Islam umumnya menjangkau pulau-pulau di sebelah timur seperti Kepulauan Kei dan Kepulauan Aru. Para pedagang asal Jawa dan Makassar kiranya berperan sebagai perantara yang meluaskan pengaruh Islam di wilayah Maluku Tenggara.

Orang-orang Eropa mencapai Kepulauan Maluku pada abad ke-16 yang ditandai dengan kedatangan bangsa Portugis di Banda. Mereka juga menjangkau Kepulauan Maluku Tenggara dan sempat membangun benteng di Pulau Kisar dan Pulau Wokam di Kepulauan Aru. Dengan kehadiran yang terhitung sebentar, pengaruh Portugis tidaklah besar di Kepulauan Maluku Tenggara. Adalah Bangsa Belanda yang kemudian merubah sejarah Kepulauan Maluku Tenggara selama tiga abad ke depan. Setelah mencapai Maluku dan menguasai Benteng Portugis di Ambon pada tahun 1602, hegemoni Belanda atas kepulauan rempahrempah menjadi tertanam. Belanda hadir di Maluku Tenggara pada permulaan abad ke-17. Mereka mencapai Kepulauan Kei pada tahun 1606 sebelum kemudian mencapai pulau-pulau di sebelah barat.

Dinamika sosial-politik berlangsung fluktuatif hingga abad ke depan. Perlawanan-perlawanan yang dilakukan pada skala lokal membuat pemerintah Hindia Belanda akhirnya memberlakukan kebijakan kawasan tertutup bagi 
Kepulauan Maluku Tenggara. Termasuk pelarangan perdagangan antarpulau dalam wilayah ini. Kepulauan ini kemudian dilupakan selama hampir dua abad. Baru pada akhir abad ke-19 pemerintah kolonial menerapkan kebijakan Pasifikasi, yang membuka kembali wilayah ini. Menjadi bagian dari kebijakan ini adalah upaya sipilisasi bagi masyarakat dengan menginisiasi pendidikan dan meluaskan ajaran agama Kristen. Pada titik ini aktivitas para misionaris Katolik dimulai dan terbukti cukup efektif merangkul penduduk setempat (De Jonge dan van Dijk, 1995).

Adalah melalui para misionaris Katolik ini juga gambaran tentang religi tradisional di Kepulauan Maluku Tenggara dapat diamati. Sebelumnya, mulai dari awal Masehi hingga abad ke-16, bisa dikatakan tidak ada catatan yang mampu menjadi rujukan untuk mengetahui praktik religi tradisional pada masa itu. Namanama seperti Heymering, Luyke, Bar, dan Dommers termasuk dalam kelompok misionaris awal. Sementara Drabbe mewakili misionaris Katolik yang banyak memberi sumbangan besar bagi pengetahuan budaya di wilayah ini. Termasuk hal-hal yang terkait dengan religi tradisional. Tentu selain para misionaris, para pegawai Pemerintah Hindia Belanda seperti Riedel, Schaade dan Gooszen menjadi pihak-pihak yang banyak memberi kontribusi pengetahuan budaya di Kepulauan Maluku Tenggara (Ririmasse, 2011).

Catatan dan hasil kajian mereka menjadi sumber tentang bagaimana sebelum kedatangan Islam dan meluasnya pengaruh agama Kristen, religi tradisional menjadi rujukan utama bagi seluruh penduduk yang mendiami wilayah luas ini. Eksistensi kepercayaan setempat ini utamanya ditunjukan pada keberadaan patung-patung dewa dan leluhur yang dipuja baik dalam lingkup keluarga maupun secara komunal dalam lingkup desa. Itulah mengapa altar dan mezbah untuk pemujaan biasanya didirikan di tengah desa jika mengacu pada rencana ruang pemukiman masa lalu di Kepulauan Maluku Tenggara.

Keberadaan leluhur bagi masyarakat Maluku Tenggara di masa lalu memang esensial. Mereka dipuja sebagai sumber asal- usul dan jati diri. Dalam konsep religi tradisional setempat, leluhur juga diyakini memiliki kuasa untuk mengatur nasib komunitas yang masih hidup. Meski tak kasat mata, kehadiran leluhur diyakini menentukan keberlangsungan kehidupan alam semesta. Sebagaimana terekam dalam berbagai catatan etnohistoris para misionaris dan pegawai Hindia Belanda, pemahaman atas kosmologi tradisional masyarakat di Maluku Tenggara kiranya merupakan pintu untuk memahami eksistensi leluhur di wilayah ini.

\section{Kosmologi dan Leluhur}

Dalam pengertian yang paling sederhana pada kosmologi tradisional di Maluku Tenggara, seorang individu bisa dipandang sebagai perpaduan dua elemen utama: yang pertama adalah elemen yang dikenal sebagai mormorsol yang secara harafiah dapat diartikan sebagai kekuatan vital. Elemen kedua disebut sebagai dmeir dan dapat diartikan sebagai 'kedirian'. Mormorsol adalah bagian dari individu yang mewujud dalam bentuk fisikal dan dapat diamati pada manusia dalam bentuk pertumbuhan dan perkembangan tubuh serta dinamika gerak badan. Kehadiran mormorsol pada seorang laki-laki secara khusus ditunjukkan dengan desah nafas dan degup jantung. Elemen ini memang terkait erat dengan darah (Ririmasse, 2011; de Jonge dan van Dijk, 1995).

Dmeir adalah bagian yang jauh lebih rumit dan mengacu pada bagian dari individu yang tidak melekat pada aspek fisik dan terkait dengan jati diri seseorang. Dalam praktiknya terdapat dua aspek yang membentuk elemen ini. Pertama bahwa aspek ini mengacu pada karakteristik personal sesesorang yang terkait dengan nama, bentuk wajah, suara, bentuk tubuh dan bayangan dari tubuh itu sendiri. Masyarakat tradisional umum menyebut aspek ini sebagai 'bayangan' atau 'roh' 
dan lebih terkait dengan identitas sosial seseorang. Dmeir sangat berhubungan dengan reputasi, imaji seseorang dalam masyarakat. Hal penting yang membedakan antara dua elemen ini adalah bahwa apa yang dsebut sebagai dmeir seseorang bersifat abadi. Setelah kematian dmeir diyakini tetap tinggal dalam masyarakat meski fisik meluruh seiring tubuh yang musnah (Ririmasse, Ibid; de Jonge dan van Dijk, Ibid.).

Eksistensi dmeir bersifat kekal. Karena itu masyarakat Maluku Tenggara kemudian membuat patung kayu sebagai wahana bagi roh si mati untuk berdiam. Melalui keberadaan aneka patung ini, komunikasi antara mereka yang hidup dengan si mati dapat dilanjutkan. Kehadiran patung-patung ini dalam lingkup masyarakat dipandang setara dengan kehadiran figur leluhur yang dipuja itu sendiri. Patung-patung ini biasanya ditempatkan di bagian bubungan rumah untuk tingkat keluarga. Pada tingkat desa biasanya patung ini diletakkan di rumah keluarga yang dipandang menjadi keturunan langsung pendiri desa. Di beberapa tempat, seperti di Kepulauan Babar, patung-patung leluhur ini juga disimpan dalam gua-gua yang berada di dekat desa. Dengan pencahayaan yang minimal, suasana mistis muncul sebagai kondisi yang dibutuhkan untuk berkomunikasi dengan leluhur (Ririmasse, 2011; de Jonge dan van Dijk, 1995).

Biasanya patung-patung ini dikeluarkan hanya pada saat dilangsungkan upacara adat besar bagi desa. Di Dawera dan Dawelor biasanya patung-patung leluhur dikeluarkan pada saat upacara kesuburan besar yang dikenal sebagai porka. Dalam upacara ini kehadiran seluruh anggota masyarakat adalah keharusan. Baik mereka yang masih hidup ataupun yang telah mati. Kehadiran para leluhur dan keluarga yang telah meninggal dalam rangkaian upacara besar ini diwakili oleh keberadaan patung-patung khas tersebut. Keberadaan mereka dalam upacara ini diyakini memberi restu dan nasib baik bagi kelangsungan kehidupan di desa. Dalam upacara ini, patung-patung leluhur ditempatkan di atas altar berbentuk struktur batu yang berada di tengah-tengah desa (Ririmasse, 2011).

Praktik pemujaan leluhur dan religi tradisional ini baru mulai berangsur hilang pada akhir abad ke-19 hingga pertengahan abad ke-20. Kondisi ini merupakan dampak dari kebijakan Pasifikasi yang dilakukan Pemerintah Kolonial. Selain mendorong peningkatan kesejahteraan dan pendidikan sebagai bagian dari politik etis, Pemerintah Kolonial juga mendorong penyebaran agama Kristen untuk memperkenalkan 'peradaban' bagi masyarakat tradisional di wilayah ini. Ekses dari penyebaran agama Kristen dan kehadiran para rohaniwan ini sangatlah terasa bagi keberadaan religi tradisional yang telah berlangsung berabad-abad. Setelah memeluk agama Kristen, masyarakat dilarang untuk menyimpan dan membuat patungpatung leluhur ini karena dipandang bertentangan dengan ajaran Nasrani. Para misionaris Protestan adalah kelompok rohaniwan yang paling keras menerapkan kebijakan ini. Ribuan patung-patung bernilai seni dan sejarah tinggi ini dimusnahkan. Ribuan lainnya diangkut ke Eropa dan menjadi koleksi museum dan kolektor pribadi (Ririmasse, 2011).

Kini, patung-patung leluhur yang berasal dari abad silam sudah hampir hilang sama sekali dari Kepulauan Maluku Tenggara. Keberadaan aneka karya seni tinggi ini hanya dapat ditelusuri pada berbagai koleksi museum dan kolektor pribadi. Museum-Museum di Eropa adalah institusi yang banyak menyimpan patungpatung asal Maluku Tenggara dengan karakter khas ini. Sementara dalam lingkup nasional, Museum Negeri Siwa Lima di Ambon menjadi rumah bagi berbagai patung serupa. Jejak lain dapat diamati melalui keberadaan ragam struktur altar di tengah desa di berbagai lokasi di Maluku Tenggara yang telah banyak kehilangan nilai fungsi aslinya. 
Keberadaan objek-objek spesifik ini kiranya menjadi penanda materi atas fenomena pemujaan leluhur masa lalu di Kepulauan Maluku Tenggara. Selain merepresentasikan figur leluhur, eksistensi benda-benda ini sejatinya juga menjadi wahana representasi identitas bagi kelompok masyarakat di Kepulauan Maluku Tenggara. Aspek-aspek spesifik terkait jati diri si mati dimaterialisasi sebagai media untuk menciptakan ikatan komunal bagi kelompok masyarakat yang menjadi keturunannya. Karakter geografis Maluku Tenggara yang memiliki profil kepulauan yang luas dan kompleks, tergambar juga dalam luasnya variasi representasi material wahana pemujaan leluhur. Setiap pulau dan kepulauan serta setiap komunitas, menampilkan bentukbentuk materialisasi leluhur yang bervariasi satu sama lain mengacu pada latar narasi sejarah budaya masing-masing.

\section{Wahana Pemujaan Leluhur di Kepulauan Maluku Tenggara}

Beragamnya manifestasi wahana pemujaan leluhur kiranya merupakan konsekuensi atas geografi kawasan yang berkarakter kepulauan. Dengan eksistensi komunitas dalam kawasan yang menyebar, variasi dalam representasi adalah wajar. Fenomena ini tergambar dalam perbedaan visualisasi antara pulau-pulau di sebelah barat yang mencakup antara lain Lakor dan Damar, dengan pulau-pulau di sebelah Timur yang mencakup Tanimbar dan Kei. Karakter genealogis di sebelah barat melekat pada garis keturunan perempuan. Itulah mengapa patung leluhur yang ditampilkan biasanya mencerminkan profil seorang wanita. Pada pulau-pulau di sebelah timur, laki-laki menjadi panduan garis keturunan. Karena itu figur patung leluhur adalah maskulin sifatnya. Lepas dari perbedaan secara konseptual dan fisikal, representasi aneka patung leluhur ini juga melekat dengan nuansa ideologissimbolis yang melingkupinya sebagaimana diulas di bawah ini.

\section{Patung Leluhur di Pulau Lakor: Berawal dari Wanita}

Komunitas tradisional yang mendiami Kepulauan Leti Moa Lakor menganut garis keturunan matrilineal, dimana keturunan melalui garis wanita menjadi acuan. Representasi material atas penggambaran leluhur juga mengacu pada konsep ini, sebagaimana teramati dalam aneka patung 'nenek moyang'. Patungpatung leluhur yang dipandang paling penting dalam konstruksi budaya masyarakat di gugus pulau ini adalah patung nenek moyang pertama. Masyarakat biasanya menyebut patung ini sebagai luli. Dalam bahasa setempat luli juga diartikan sebagai keramat. Oleh para pemerhati studi budaya, patung-patung luli ini dipandang sebagai salah satu representasi seni kriya terbaik dalam kawasan Maluku Tenggara.

Penggambaran luli seringkali dalam gaya yang memadukan antara realisme dan abstrak yang kaya simbol. Gaya realisme dapat diamati dari bentuk yang berupaya menampilkan figur antromorfik. Sementara gaya abstrak dapat diamati dari penggambaran yang memadukan elemen antromorfik dengan bentuk-bentuk seperti perahu dan pohon. Patung-patung ini memang kaya dengan makna simbolik. Luli, sebagai penggambaran leluhur wanita, biasanya lekat dengan simbol kesuburan. Hal ini dapat diamati dari upaya menggambarkan elemen seperti payudara secara nyata pada patung ini. Bentuk perahu seringkali secara simbolis diwakili oleh bentuk tangan patung yang direntangkan melebar. Perahu dalam konsepsi budaya tradisional masyarakat Maluku Tenggara memang identik dengan kesuburan dan lahirnya kehidupan baru. Wanita dipandang sebagai sebuah perahu, yang menyusul kehadiran laki-laki sebagai nakhoda, akan melahirkan satu kehidupan baru sebagai perpaduan unsur keduanya. Perahu juga seringkali dipandang sebagai perlambang rahim. Wahana kelahiran sebuah kehidupan baru. Konsep tentang kesuburan juga diwakili oleh motif pohon. 
Biasanya motif ini diterakan sebagai bagian dari luli untuk mempertegas fungsi simboliknya yang lekat dengan tema kesuburan. Pada beberapa patung luli motif pohon justru tampil sebagai elemen sentral. Figur manusia kemudian ditampilkan misalnya dengan menerakan tangan yang keluar terbentang dari motif pohon ini.

Walau memiliki berbagai variasi, luli senantiasa memiliki makna yang baku. Hadir sebagai representasi leluhur yang memberi status bagi keturunannya. Kedudukan keluarga yang menjadi keturunan sang leluhur biasanya ditampilkan secara menyolok dalam penggambaran patung. Fenomena ini antara lain ditunjukkan dengan penggambaran motif hiasan kepala emas yang merupakan perlambang marna, kelompok keluarga bangsawan setempat. Beberapa patung lain juga menampilkan motif mas tanduk, yaitu kalung mas yang biasanya digunakan kelompok keluarga bangsawan. Dengan nilai sakral yang dimiliki, luli biasanya diberi tempat khusus di dalam rumah. Bentuknya seringkali berupa altar kecil atau tempat khusus pada bubungan rumah. Sudah menjadi kebiasaan ketika keluarga berkembang dan membentuk sebuah desa, maka luli akan ditempatkan pada 'rumah tua' yang dianggap mewakili asal usul seluruh keluarga.

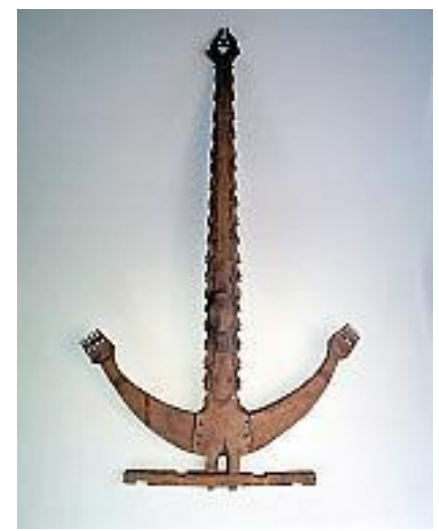

Foto 1. Luli Koleksi Museum Etnologi Nasional di Leiden yang Berasal dari Kepulauan Leti
(Sumber: Koleksi Museum Etnologi

Nasional Leiden)

Leluhur di Damar: Represtasi pada Patung Papan

Konsep tentang leluhur di Damar sejatinya hampir serupa dengan apa yang ditemukan di Lakor. Di Damar, garis keturunan juga ditarik dari wanita. Karena itu representasi patung leluhur juga diwakili oleh karakter leluhur wanita. Aspek yang membedakan antara Damar dan Lakor adalah cara penggambaran. Dimana, jika di Lakor representasi digambarkan dalam bentuk patung lepas, maka di Damar figur leluhur ditampilkan dengan bentuk patung yang dilekatkan pada papan kayu berhias.

Motif yang ditampilkan pada patung leluhur di Damar serupa dengan apa yang ditampilkan di Lakor. Pola hias tumbuhan, pohon dan perahu, diterakan menyatu dengan figur manusia. Dengan demikian makna simbolik yang dikandung juga masih memilki relevansi. Elemen seperti pohon, perahu dan wanita, adalah perlambang kesuburan. Menggambarkan potensi untuk memberikan kehidupan baru dalam penyatuan dengan unsur laki-laki. Patung leluhur di Damar juga dipandang sakral dan diberi tempat yang khusus baik di rumah dan lingkup komunitas desa.
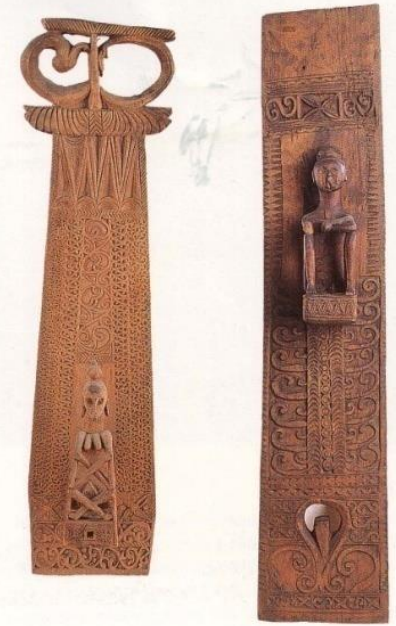

Foto 2. Patung Leluhur dari Pulau Damar 


\section{Tavu: Altar Leluhur di Kepulauan Tanimbar}

Representasi patung leluhur dari Kepulauan Tanimbar ini barangkali adalah yang paling terkenal di antara varianvarian tema serupa dalam kawasan. Bagi mereka yang menaruh minat pada sejarah budaya Kepulauan Maluku Tenggara tentu memahami objek terkenal ini. Salah satu tavu yang paling popular kini menjadi koleksi Museum Etnologi Nasional Leiden di Negeri Belanda.

Tavu adalah patung papan dengan gaya dua dimensi yang direka sebagai wahana pemujaan leluhur di Kepulauan Tanimbar. Biasanya direkayasa dengan tinggi antara satu hingga satu setengah meter dalam bentuk figur antromorfik dengan tangan terbentang. Menimbang konsep garis keturunan di Tanimbar yang bersifat patrilineal, maka figur yang dimunculkan biasanya laki-laki. Objek ini menjadi bagian dari konstruksi fisikal pada rumah tradisional di Tanimbar dan seringkali diletakkan tepat setelah pintu masuk. Hanya mereka yang memiliki latar belakang keluarga bangsawan yang boleh memiliki tavu dengan pola hias yang kaya dan indah.

Istilah Tavu dapat diartikan sebagai 'permulaan' atau 'asal'. Sebuah istilah yang terkait dengan leluhur pertama yang menjadi cikal bakal pembentuk keluarga. Pribadi yang dipandang mengumpulkan beragam pusaka keluarga yang berharga. Tavu berbeda dengan patung leluhur di Lakor dan Damar yang dipuja secara mandiri. Tavu biasanya menjadi semacam altar pemujaan. Objek ini diletakkan menyatu dengan nampan berisi tulang leher leluhur yang telah meninggal bersama dengan patung-patung leluhur dari masa yang lebih muda atau biasa disebut walut. Pada tavu inilah kepala keluarga atau kelompok biasanya duduk dalam setiap pertemuan keluarga atau melakukan pemujaan dan membawa sesaji.

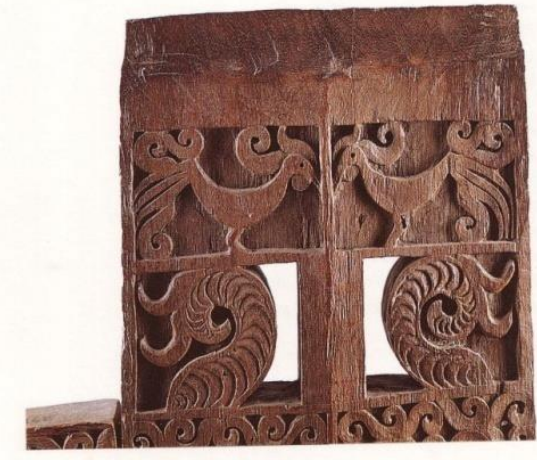

Foto 3. Pola Hias pada Salah Satu Tavu Asal Tanimbar

Figur dan pola hias yang ditampilkan pada tavu bisa sangat beragam. Selain motif antromorfik, figur hewan juga umum diterakan. Biasanya hewan yang menjadi pilihan pola hias adalah ayam dan ikan yang merupakan perlambang pemburu dan prajurit. Sebuah konsep yang juga umum dikenal di berbagai tempat di Kepulauan Maluku Tenggara. Terdapat juga motif kerang yang merupakan perlambang hasil buruan atau kepala manusia. Pada beberapa tavu gigi geligi dari musuh yang dibunuh bahkan juga dilekatkan. Keberadaan elemenelemen hias ini memang terkait erat dengan simbolisasi status keluarga. Mereka hadir sebagai wahana untuk menunjukkan kejayaan keluarga dan posisi yang terpandang dalam masyarakat.

\section{Sedeu: Patung-Patung Pendiri Desa di Kepulauan Kei}

Patung leluhur di Kepulauan Kei dikenal dalam bahasa setempat sebagai sedeu. Objek ini biasanya dipandang sebagai representasi leluhur pertama yang membentuk masyarakat dan mendirikan desa. Struktur organisasi sosial yang ada di Kei serupa dengan yang ada di Tanimbar. Dimana garis keturunan dilekatkan melalui laki-laki. Karena itu sedeu biasanya merupakan perlambang leluhur laki-laki. Sedeu biasanya dibuat dari bahan kayu atau batu dengan tinggi yang bisa mencapai satu setengah meter. Figur 
leluhur digambarkan dalam bentuk antromorfik dengan posisi berdiri, duduk atau memegang senjata.

Patung leluhur ini biasanya dipandang juga sebagai pelindung desa. Di masa lalu, biasanya patung-patung ini diletakkan berdiri di atas altar yang dibangun di tengah-tengah desa. Tepat di samping mezbah atau batu penyembahan dengan ukuran besar. Sayangnya, fenomena ini sudah tidak lagi ditemui di Kepulauan Kei. Bahkan sejak satu abad silam. Namun jejak-jejak altar yang disebut dengan woma, masih dapat ditemukan. Patung-patung leluhur dari Kei sendiri saat ini menjadi koleksi museummuseum di Eropa. Salah satunya adalah museum Etnologi Nasional Leiden di Negeri Belanda. Salah satu sedeu yang terkenal adalah Werwat. Patung leluhur yang berasal dari Desa Gelanit di Kei Kecil dan kemudian dikoleksi dan dibawa ke Belanda oleh Goozsen pada awal abad ke-20.

\section{Woma: Penanda Kehadiran Leluhur dalam Ruang}

Selain wahana dalam bentuk patung, salah satu elemen lain terkait komemorasi leluhur di Kepulauan Maluku Tenggara diwakili oleh keberadaan struktur batu sebagai altar bagi patung-patung sakral tersebut. Biasanya struktur altar ini dibentuk oleh batu yang disusun di tengahtengah desa. Istilah yang digunakan untuk altar ini beragam. Di Kepulauan Kei biasanya disebut dengan Woma. Di Kepulauan Tanimbar biasanya disebut sebagai Natar. Keberadaan struktur batu ini adalah sentral karena menjadi wahana dimana patung-patung leluhur dan dewa selalu diletakkan. Woma dan Natar senantiasa dipandang sebagai pusat desa. Axis mundus bagi setiap pemukiman tradisional. Pada lokasi struktur inilah biasanya aneka sesajen diletakkan sebagai bentuk penghormatan kepada leluhur. Saat ini keberadaan woma dan natar masih dilestarikan, meski praktik pemujaan leluhur telah menghilang dan patung- patung terkait praktik ini telah punah. Keberadaan struktur altar ini adalah penting karena menjadi penanda material bahwa praktik-praktik religi tradisional pernah menjadi bagian dari profil sosial masyarakat di Kepulauan Maluku Tenggara. Woma dan natar menjadi penanda material, bagaimana wahana pemujaan leluhur ditempatkan dalam rencana ruang tradisional.

Tampil bervariasi antara satu pulau dengan pulau lainnya, jelas terlihat bahwa pemujaan leluhur adalah bagian sentral dari praktik religi tradisional pada masa lalu di Kepulauan Maluku Tenggara. Keberadaan patung-patung leluhur dalam berbagai ragam merupakan wahana representasi figur leluhur bagi setiap keluarga dan masyarakat. Penghormatan dan pemujaan umumnya ditujukan kepada leluhur pertama yang meletakkan dasar bagi dibentuknya satu kelompok dan komunitas. Kehadiran sturktur altar batu dalam rencana ruang tradisional melengkapi jejak materi terkait praktik kepercayaan tradisional ini. Eksistensi objek-objek ini dalam berbagai manifestasi materi merupakan penanda fisikal bagi identitas komunal di Kepulauan Maluku Tenggara.

\section{Pemujaan Leluhur dan Pengetahuan Religi Tradisional: Perannya Bagi Pengembangan Studi Arkeologi dalam Kawasan}

Cakupan luas profil sejarah budaya pemujaan leluhur dan representasinya telah dibahas di atas. Dimana telah ditinjau latar historis praktik religi tradisional ini serta ragam manifestasi materi yang mewakilinya. Lebih jauh juga telah dibahas aspek ideologis yang melatari praktik pemujaan leluhur dalam kawasan. Pertanyaan yang masih harus dijawab adalah, terkait bagaimana peran pengetahuan spesifik ini bagi pengembangan studi arkeologi dalam kawasan.

Salah satu penanda khas dalam kajian sejarah budaya di Kepulauan Maluku Tenggara adalah keberadaan 
pemukiman kuna dari masa pra-kolonial. Profil khas aneka pemukiman ini adalah keletakannya yang berada di dataran tinggi dengan akses minimal dari berkarakter defensif. Ciri khas sebagai tempat pertahanan ditunjukkan dengan keberadaan tembok keliling yang pada beberapa situs tingginya bisa mencapai 3 meter. Karakter ini menjadi cetak biru rencana ruang pemukiman tradisional di Maluku Tenggara hingga kedatangan Orang Eropa. Dimana pada akhir abad ke-19 dan awal abad ke-20 dikeluarkanlah kebijakan pasifikasi atas kawasan ini yang antara lain mencakup relokasi pemukiman masyarakat dari dataran tinggi ke kawasan pesisir. Tujuan relokasi ini adalah untuk mempermudah pengawasan pemerintah kolonial atas masyarakat dalam kawasan (Ririmasse, 2010).

Konsep pemukiman tradisional di Maluku Tenggara biasanya ditandai dengan pembagian ruang yang mengacu pada kosmologi perahu sebagai simbol. Dimana rumah-rumah dari setiap kelompok keluarga (biasanya berjumlah empat sampai lima) ditata sedemikian rupa mengacu pada arah mata angin yang dikenal dalam pelayaran (Ririmasse, 2007). Pada pusat tata ruang tradisional ini biasanya diletakkan sebuah altar yang dibentuk dari susunan batu sebagai pusat desa. Adalah pada titik ini patung-patung leluhur biasanya diletakkan di tengahtengah desa. Selain dalam bentuk altar, keberadaan pusat desa juga dapat diwakili dari keberadaan rumah keluarga pertama yang mendiami desa. Pada rumah inilah aneka patung leluhur dan pusaka desa juga bisa disimpan.

Pengetahuan atas praktik pemujaan leluhur dan manifestasi materinya, kiranya dapat memperkaya studi arkeologis atas berbagai situs bekas pemukiman kuna yang tersebar luas di Kepulauan Maluku Tenggara. Menimbang luasnya variasi penerapan rencana ruang tradisional dalam kawasan, keberadaan pengetahuan spesifik terkait pemujaan leluhur dapat mempertajam kedalaman kajian ruang tradisional pada situs-situs spesifik di wilayah ini. Pengetahuan konseptual terkait praktik khas ini merupakan unsur yang memberi nafas dan warna konseptual dan kosmologis bagi kajian fisikal atas ruang tradisional dalam arkeologi.

Aspek lain yang juga potensial untuk dikaji dalam studi arkeologi di Kepulauan Maluku Tenggara adalah terkait dinamika sosial masa lalu dalam kawasan. Religi tradisional dan perubahannya adalah salah satu elemen sentral dalam tinjauan dinamika sosial di wilayah ini. Rentang waktu yang baru berkisar satu hingga dua abad lalu sejatinya menyisakan ruang yang longgar untuk mendapatkan gambaran yang lebih nyata terkait proses perubahan religi dalam kawasan. Kekayaan sumbersumber historis asing dapat menjadi rujukan utama untuk meninjau tema khas ini. Pemujaan leluhur merupakan salah satu elemen sentral dalam aktivitas religi tradisional di Maluku Tenggara masa lalu. Karenanya pengetahuan atas praktik pemujaan leluhur dan ragam representasi materialnya merupakan masukan berharga bagi kedalaman kajian terkait dinamika sosial masa lalu dalam kawasan ini.

Hal terakhir yang layaknya dicermati adalah kondisi bahwa tinjauan atas praktik pemujaan leluhur di Maluku Tenggara merupakan bagian dari studi sejarah budaya Austronesia yang menjadi salah satu isu utama dalam studi arkeologi Asia-Pasifik. Aspek identitas merupakan salah satu unsur penting dalam studi diaspora Austronesia yang berskala kolosal ini. Karena itu tinjauan atas aspek ideologis terkait asal usul dan hirarki sosial menjadi elemen-elemen yang mendapat perhatian dalam studi ini. Kepulauan Maluku Tenggara merupakan rumah bagi kelompok bahasa Austronesia yang dikenal sebagai Central Malayo Polynesian dengan lebih dari 20 sub-rumpun bahasa. Upaya spesifik untuk melekatkan tema Austronesia dalam studi Arkeologis di Maluku Tenggara hampir belum pernah dilakukan. Model pemujaan leluhur dan religi tradisional dapat menjadi salah satu pintu 
masuk untuk mengisi ruang kosong dimaksud. Identifikasi atas jejak budaya khas ini dan komparasi dengan kawasan sekitar dapat menjadi wahana yang memperkaya pengetahuan arkeologis terkait diaspora penutur bahasa Austronesia di Asia Pasifik.

\section{PENUTUP}

Pemujaan leluhur adalah praktik religi tradisional yang dianut secara universal. Diadopsi juga secara luas dalam lingkup komunitas tradisional masa lalu di Asia Tenggara, pengaruh kepercayaan khas ini juga menjangkau wilayah Kepulauan Maluku Tenggara. Sebelum masuk dan meluasnya pengaruh Islam pada abad ke-15 dan ajaran Nasrani pada abad ke-17, pemujaan leluhur merupakan rujukan utama bagi praktik religi dalam kawasan. Fenomena ini berlangsung hingga menjelang paruh pertama abad ke20 dan berangsur menghilang meyusul kebijakan pasifikasi yang diterapkan Pemerintah Hindia Belanda.

Bukti-bukti materi religi tradisional ini ditunjukkan dengan keberadaan patungpatung leluhur yang menjadi wahana utama praktik pemujaan. Mereka direka dalam berbagai variasi formal dan dilekatkan dengan aspek ideologissimbolis terkait sejarah dan asal-usul komunitas. Keberadaan struktur altar batu sebagai bagian dari rencana ruang tradisional juga menjadi bukti lain atas praktik pemujaan leluhur di Kepulauan Maluku Tenggara. Kehadiran ragam jejak fisikal ini dapat dipahami sebagai bentuk materialisasi identitas yang melekatkan kebersamaan komunal dan melegitimasi eksistensi leluhur dengan kelompok keturunan yang masih hidup hingga saat ini.

Dalam kaitan dengan pengembangan studi arkeologi dalam kawasan, pengetahuan atas praktik pemujaan leluhur ini dapat memperkaya dan memperdalam kajian arkeologis terkait tiga aspek yaitu: pertama, studi pemukiman masa lalu khususnya dari masa pra-kolonial, kedua, dinamika sosial masa lalu dalam kawasan utamanya menyangkut pergeseran religi, ketiga, eksistensi pengetahuan spesifik ini bagi kajian budaya penutur bahasa Austronesia dalam kawasan khususnya dalam kaitan dengan isu identitas dan ideologi cikal-bakal.

\section{DAFTAR SUMBER}

Bell.C 1992.

Ritual Theory, Ritual Practice. Oxford: Oxford University Press.

Carpenter, Mary Yeo. 1996.

Familism and Ancestor
Veneration: A Look at Chinese
Funeral Rites. Missiology 24.

Coe, K. 2003.

The Ancestress Hypothesis: Visual Art as Adaptation. New Jersey: Rutgers University Press.

Connerton, Paul.1989.

How Societies Remember. Cambridge: Cambridge University Press.

De Marrais, E. et. al. 1996.

Ideology, Materialization, and Power Strategies. Current Anthropology Vol. 37. No. 1. Chicago: University of Chicago Press. pp. 15-31.

Dhavamony, M. 1995 .

Fenomenologi Agama. Yogyakarta: Kanisius.

Dillehay, T.D. 1990.

Mapuche ceremonial landscape, social recruitment, and resource rights. World Archaeology. Vol. 22.No 2. Pp 223-241.

Hastrof, C.A. 2003. 
Community with the ancestors: Ceremony and social memory in the middle formative at Chiripa Bolivia. Journal of Anthropological Archaeology (22).4: 305332.

Kusumawati, Ayu. Tanpa tahun.

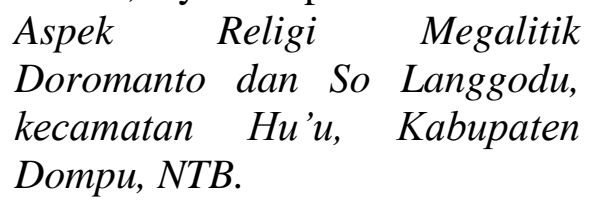

David L. Sills (ed.). 1968.

International Encyclopedia of Social Sciences. New York: Macmillan and Free Press, vol. 13: 520-526.

Mahmud, Irfan. 2008.

Austronesian Cultural Traditions among the Toraja Tribe. Austronesian in Sulawesi. Simanjuntak, Truman (Ed.). Yogyakarta: Galang Press.

Radin, Paul. 1957.

Primitive Religion: It's Nature and Origin. Dover: Dover Publications.

Ririmasse, M. 2008.

Visualisasi tema perahu dalam rekayasa situs arkeologi di Maluku. Dalam Naditira Widya Volume 2 No. 1. Banjarmasin: Balai Arkeologi Banjarmasin. 2007.

Ruang Sebagai Wahana Makna: Aspek Simbolik dalam Rekayasa Pemukiman Kuna di Maluku. Kapata Arkeologi Vol. 3 No. 6. Ambon: Balai Arkeologi Ambon.
Arkeologi Pulau-Pulau Terdepan di Maluku: Sebuah Tinjauan Awal. Kapata Arkeologi Vol. 6 No. 10. Ambon: Balai Arkeologi Ambon. 2011.

Laut untuk Semua: Materialisasi Budaya Bahari di Kepulauan Maluku Tenggara. Makalah disajikan dalam Evaluasi Hasil Penelitian Arkeologi 2011. Banjarmasin. Tanpa tahun.

Koleksi Budaya Bendawi Maluku Tenggara di Museum Etnologi Nasional Leiden (dalam persiapan).

Sonjaya, Jajang. 2008.

Melacak Batu, Menguak Mitos.

Wiradnyana, Ketut. 2011.

Prasejarah Sumatera Bagian Utara: Kontribusinya pada Kebudayaan Kini. Jakarta: Yayasan Obor Indonesia. 